deducing evolving carbon fluxes during the past 15 years.

Three independent tracer approaches constrain rates of $\mathrm{CO}_{2}$ uptake by the oceans. One approach is based on the uptake rate by the oceans of ${ }^{14} \mathrm{CO}_{2}$ generated by nuclear bomb tests, on the difference in partial pressures of $\mathrm{CO}_{2}$ between the atmosphere ${ }^{4,5}$ and the surface ocean, and models of ocean mixing ${ }^{6}$.

A second method examines the rate of change of the stable-isotope ratio of carbon in the atmosphere and sea water ${ }^{7-9}$. Burning of fossil fuel $\mathrm{CO}_{2}$ (with ${ }^{13} \mathrm{C} /{ }^{12} \mathrm{C} \sim-28$ parts per thousand, relative to the PDB-1 standard) and its invasion into the oceans is causing the isotope ratio of total dissolved $\mathrm{CO}_{2}$ in surface sea water $\left({ }^{13} \mathrm{C} /{ }^{12} \mathrm{C} \sim+2\right.$ parts per thousand) to decrease.

The third technique ${ }^{10}$ is to measure the $\mathrm{CO}_{2}$ concentration and the ${ }^{13} \mathrm{C} /{ }^{12} \mathrm{C}$ ratio of atmospheric $\mathrm{CO}_{2}$ as a function of latitude, in order to partition the total uptake rate between the oceans and the land biosphere $\left(\mathrm{CO}_{2}\right.$ uptake by the land biosphere discriminates against the heavier isotope). All three $\mathrm{CO}_{2}$ tracer approaches estimate oceanic uptake at about $2 \mathrm{Gt} \mathrm{C} \mathrm{yr}^{-1}$ for various periods between 1980 and 1994 .

On land, recent history is more complicated. The global net $\mathrm{CO}_{2}$ uptake by the land biosphere estimated by Keeling et al. ${ }^{1}, 2.0 \mathrm{Gt} \mathrm{C} \mathrm{yr}^{-1}$ for 1991-94, is in good agreement with that of the last tracer method $^{10}, 2.6 \mathrm{Gt} \mathrm{C} \mathrm{yr}{ }^{-1}$ for 1992-93, and both these approaches indicate that the land biosphere was an important $\mathrm{CO}_{2}$ sink during the early years of the current decade. But in contrast, several studies ${ }^{11}$ suggest that between 1980 and 1989 the biosphere was roughly in balance.

The $\mathrm{CO}_{2}$ mass balance during this earlier period is constrained by the modelled estimates of oceanic $\mathrm{CO}_{2}$ uptake outlined above, as well as studies of the $\mathrm{O}_{2} / \mathrm{N}_{2}$ ratio of air in the firn (the partly compacted layer of snow) at the surface of polar glaciers $^{12}$. According to these results, fossil fuel emissions during the $1980 \mathrm{~s}(\sim 5.4 \mathrm{Gt}$

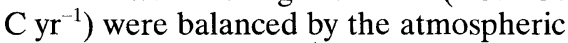
increase (3.2 $\mathrm{Gt} \mathrm{C} \mathrm{yr}^{-1}$ ) and oceanic up-

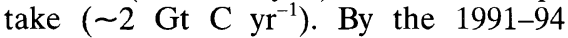
period, emissions had risen to about

1. Keeling, R. F., Piper, S. C. \& Heimann, M. Nature 381 , 218-221 (1996)

2. Keeling, R. F. \& Shertz, S. R. Nature 358, 723-727 (1992).

3. Bender, M., Ellis, T., Tans, P., Francey, R. \& Lowe, D. Globl biogeochem. Cycles 10, 9-21 (1996).

4. Keeling, C. D. et al. in Aspects of Climate Variability in the Pacific and Western Americas (ed. Peterson, D. H.) 165-236 (American Geophysical Union, Washington DC 1989).

5. Conway, T. J. et al. J. geophys. Res. 99, 22831-22855 (1994).

6. Sarmiento, J. L., Orr, J. C. \& Siegenthaler, U. J. geophys. Res, 97, 3621-3645 (1992)

Ouay, P. D., Tilbrook, B. \& Wong, C. S. Science $\mathbf{2 5 6}$ 74-79 (1992)

8. Tans, P. P., Berry, J. A. \& Keeling, R. F. Globl biogeochem. Cycles 7, 353-368 (1993).

9. Heimann, M. \& Maier-Reimer, E. Globl biogeochem. Cycles 10, 89-110 (1996).
$6 \mathrm{Gt} \mathrm{C} \mathrm{yr}^{-1}$, ocean uptake remained at about $2 \mathrm{Gt} \mathrm{C} \mathrm{yr}^{-1}$, and the atmospheric increase fell from $\sim 3$ to $\sim 2 \mathrm{Gt} C \mathrm{yr}^{-1}$. Tracer studies summarized above indicate that the global land biosphere took up the imbalance, $\sim 2 \mathrm{Gt} \mathrm{C} \mathrm{yr}^{-1}$.

While tracer studies suggest that the global land biosphere was nearly in $\mathrm{CO}_{2}$ balance during the $1980 \mathrm{~s}$, they nevertheless indicate that some areas were a net sink. A largely equatorial $\mathrm{CO}_{2}$ source from deforestation was compensated for by sequestration of $\mathrm{CO}_{2}$ elsewhere. If deforestation has added $1.6 \mathrm{Gt} \mathrm{C} \mathrm{yr}{ }^{-1}$ of $\mathrm{CO}_{2}$ since 1980 (ref. 13), then the rest of the land biosphere took up about $1.6 \mathrm{Gt}$ $\mathrm{C} \mathrm{yr}^{-1}$ during the decade of the 1980s and 3.6 $\mathrm{Gt} \mathrm{C} \mathrm{yr}{ }^{-1}$ between 1991 and 1994. Carbon-isotope tracer modelling ${ }^{10}$ agrees with the $\mathrm{O}_{2} / \mathrm{N}_{2}$ measurements of Keeling et al. in indicating net $\mathrm{CO}_{2}$ uptake of $\sim 3 \mathrm{Gt} \mathrm{C} \mathrm{yr}^{-1}$ by the land biosphere above $30^{\circ} \mathrm{N}$, and measurements of the $\mathrm{CO}_{2}$ uptake rate in a northern temperate forest are consistent with such rapid uptake ${ }^{14}$. Plausible causes include $\mathrm{CO}_{2}$ fertilization of the land biosphere ${ }^{15,16}$, nitrogen fertilization resulting from industrial emissions ${ }^{17}$, and warmer temperatures and increased precipitation ${ }^{18}$ (but see ref. 19 for a contrary view)

During the past year or so, the rate of atmospheric $\mathrm{CO}_{2}$ rise has accelerated and is once again comparable to the average rate during the $1980 \mathrm{~s}$ ( $\mathrm{P}$. Tans, personal communication). This observation emphasizes the dynamic nature of the carbon cycle. Although ocean $\mathrm{CO}_{2}$ uptake does fluctuate, the land biosphere is probably the main cause of variability, some of which appears to be caused by El Niño events ${ }^{4}$. More generally, land biosphere variability must reflect changes in the small imbalance between photosynthesis and respiration, with their gross fluxes of about $100 \mathrm{Gt} \mathrm{C} \mathrm{yr}^{-1}$. Variability in that imbalance presumably relates to changes in climate, but the nature of the link is unknown.

Michael Bender is in the Graduate School of Oceanography, University of Rhode Island, Kingston, Rhode Island 02881, USA.

10. Ciais, P., Tans, P. P., Trolier, M., White, J. W. C. \& Francey, R. J. Science 269, 1098-1102 (1995)

11. Sarmiento, J. \& Bender, M. Photosynthesis Res. 39, 209-234 (1994)

12. Bender, M., Battle, M., Sowers, T. \& Tans, P. EOS 76 , F83 (1995).

13. Dixon, R. K. et al. Science 263, 185-190 (1994).

4. Wofsy, S. C. et al. Science 260, 1314-1317 (1993)

15. Bazzaz, F. A. A. Rev. Ecol. Syst. 21, 167-196 (1990)

16. Friedlingstein, P. et al. Globl biogeochem. Cycles $\mathbf{9}$, 541-556 (1995)

17. Schindler, D. W. \& Bayley, S. E. Globl biogeochem. Cycles 7, 717-733 (1993)

18. Dai, A. \& Fung, I. Globl biogeochem. Cycles, 7, 599-609 (1993).

19. Houghton, R. A. Globl biogeochem. Cycles 7, 611-617 1993).

\section{Snow growing}

GLOBAL warming poses several kinds of threat. Perhaps the most ominous is the rising of sea level from melting ice and snow. Much of the world's water is held as 'eternal snows' on the tops of high mountain ranges. If those snows stop being so eternal, there will be trouble.

A mountain top, says Daedalus, is a good place to store frozen water. The cold of altitude keeps it below zero; snow precipitates on it from the clouds that sweep over it, and piles up to even higher altitudes where the temperature is colder still. However, the stored snow has two ways of escape. It can evaporate in the sunlight, and it can descend under gravity - either rapidly as an avalanche, or slowly and viscously as a glacier. Daedalus now plans to frustrate both modes of escape.

During the Second World War, there was a scheme to adapt a North Atlantic iceberg as an aircraft carrier. Natural ice is rather weak; so the boffins planned to freeze their own iceberg, from water with a little wood-pulp in it. The resulting fibre-reinforced ice was admirably tough, and also melted much more slowly. Innumerable fibres protruded from the melting surface, forming a blanket which impeded heat transfer.

So, says Daedalus, what we need is some way of launching fine fibres into the wind traversing the Andes, the Himalayas and the other snowy mountain ranges. Once their snow is reinforced with fine fibres, it will be much more eternal. It won't creep like a glacier, nor tumble like an avalanche; and its insulated, whiskery surface will evaporate far more slowly. Less than one per cent of fibre has a dramatic effect on the toughness of ice or snow. Even so, millions of tons of fibre will be needed.

Daedalus's bold idea is to make it from our growing mountain of plastic waste. Long-chain polymers easily form fibres; some process of air-blown melt-spinning or violent pulverization should give a suitably fine, feathery, fibrous dust. Released into the air upwind of the mountains, it will be incorporated into the snowfall at the summit. But volcanic dusts are often blown halfway round the world on the wind. So rather than transporting the powder at great expense to the mountainous regions, Daedalus hopes to release it at the site of manufacture. Modern meteorology may be able to identify just that favourable wind which will carry it from the fibre factory to the far mountain of its destiny. The world's plastic waste will be put to good use, the sea level will stop rising, and the high eternal snow will rise instead.

Mountaineers will tread more surely on its toughened surface. David Jones 